\title{
Cerebrospinal fluid challenges for the diagnosis of herpes simplex infection in the central nervous system
}

\section{Desafios do exame do líquido cefalorraquidiano para o diagnóstico de infecção por herpes simplex no sistema nervoso central}

Samya Jezine DA SILVA', Mauro Jorge CABRAL-CASTRO',2, Maria Angélica GUIMARÃES ${ }^{1,3}$, José Mauro PERALTA',2, Marzia PUCCIONI-SOHLER ${ }^{1,4}$

\begin{abstract}
Herpes simplex virus (HSV) is a cause of a severe disease of the central nervous system (CNS) in humans. The demonstration of specific antibodies in the cerebrospinal fluid (CSF) may contribute to the retrospective neurological diagnosis. However, the commercial immunological tests for HSV infection are for use in serum samples. Objective: The aim of the present study was to adapt a commercial kit anti-HSV IgG used for serum samples to be performed with a CSF sample. Methods: Forty CSF specimens from 38 patients with suspected CNS HSV infection were serially diluted for detecting anti-HSV IgG by enzyme immunoassay (EIA). The same samples were also analyzed with the polymerase chain reaction (PCR). Results: The sensitivity of EIA test for HSV was 5\% (dilution 1:40) and 65\% (dilution 1:2) in CSF, and HSV DNA PCR was 15\%. The combined analysis of EIA (dilution 1:2) and PCR increased the sensitivity up to $72.5 \%$. The inflammatory CSF was associated with positive HSV PCR.

Conclusions: We demonstrated the importance to adapt serological anti-HSV IgG EIA test for CSF assays to increase the accuracy of the analysis, considering the low concentration of specific antibodies in CSF.
\end{abstract}

Keywords: herpes simplex virus; cerebrospinal fluid; enzyme immunoassay; polymerase chain reaction.

\section{RESUMO}

O vírus herpes simples (HSV) é um dos agentes causadores de uma doença grave no sistema nervoso central (SNC) em humanos. A detecção de anticorpos específicos no líquido cefalorraquidiano (LCR) pode contribuir para o diagnóstico neurológico retrospectivo. Entretanto, os testes imunológicos comerciais são para uso em amostras de soro. Objetivo: Adaptar um kit comercial sorológico anti-HSV IgG para ser utilizado no de LCR. Metodos: Quarenta amostras de LCR de 38 pacientes com suspeita de infecção por HSV no SNC foram diluídas para pesquisa de anticorpos anti-HSV IgG pelo método imunoenzimático (EIA). Além disso, as mesmas amostras também foram analisadas por reação em cadeia da polimerase (PCR). Resultados: A sensibilidade do teste EIA para o HSV consistiu em 5\% (diluição 1:40) e 65\% (diluição 1:2) no LCR, e o PCR do DNA do HSV, 15\%. A análise combinada de EIA (diluição 1:2) e PCR aumentou a sensibilidade para 72,5\%. Houve associação entre presença do LCR inflamatório e PCR positiva para HSV. Conclusões: Demonstramos a importância na adaptação previa do teste sorológico anti-HSV IgG EIA para ensaios do no LCR, a fim de aumentar a acuracia da análise, considerando a baixa concentração de anticorpos específicos no LCR.

Palavras-chave: herpes simplex virus; líquido cefalorraquidiano; técnicas imunoenzimáticas; reação em cadeia da polimerase.

Herpes simplex virus 1 (HSV-1) and 2 (HSV-2) belong to the family Herpesviridae. HSV has four elements: a core, containing the viral DNA (linear and double-stranded); an icosahedral capsid surrounding the core; a largely unstructured proteinaceous layer called the tegument, which surrounds the capsid; and an outer lipid bilayer envelope exhibiting spikes on its surface ${ }^{1}$. HSV is responsible for severe diseases of the central nervous system (CNS) in humans, as well as oral and genital cutaneous lesions ${ }^{2,3}$. Both viruses (HSV-1 and HSV-2) can trigger a broad spectrum of neurological manifestations,

${ }^{1}$ Universidade Federal do Rio de Janeiro, Programa de Pós-Graduação em Doenças Infecciosas e Parasitárias, Rio de Janeiro RJ, Brazil.

2 Universidade Federal do Rio de Janeiro, Instituto de Microbiologia, Rio de Janeiro RJ, Brazil.

${ }^{3}$ Universidade Federal do Rio de Janeiro, Hospital Universitário Clementino Fraga Filho, Serviço de Patologia Clínica, Rio de Janeiro RJ, Brazil.

«Universidade Federal do Estado do Rio de Janeiro, Escola de Medicina e Cirurgia, Rio de Janeiro RJ, Brazil.

Samya Jezine DA SILVA (iD) https://orcid.org/0000-0003-1978-0548; Mauro Jorge CABRAL-CASTRO iD https://orcid.org/0000-0002-1755-999X;

Maria Angélica GUIMARÃES (iD https://orcid.org/0000-0002-5364-7831; José Mauro PERALTA iD https://orcid.org/0000-0002-2615-4820; Marzia

PUCCIONI-SOHLER ID https://orcid.org/0000-0001-6007-9142

Correspondence: Marzia Puccioni Sohler; Av. N. Sra. de Copacabana, 1052 / Sala 1002; 22020-001 Rio de Janeiro RJ, Brazil.E-mail m_puccioni@yahoo.com.br Conflict of Interest: There is no conflict of interest to declare.

Received on December 27, 2018; Received in its final form on September 3, 2019; Accepted on October $24,2019$. 
such as meningitis, encephalitis, meningoencephalitis, myelitis, and radiculitis ${ }^{4,3}$.

The diagnosis of HSV infection in the CNS is based on the early detection of viral DNA with the polymerase chain reaction (PCR) in the cerebrospinal fluid (CSF). The sensitivity of this method is greater over the first week after symptoms onset or before treatment ${ }^{5}$. From seven to 10 days after that, the diagnosis can be determined by the presence of antibodies against the viral antigen ${ }^{5,6}$. The presence of IgM indicates recent primary infection being rarely detected in the CSF, whereas the specific IgG demonstration supports the retrospective diagnosis of the herpetic infection in the CNS and may persist for years ${ }^{7}$. The demonstration of the intrathecal synthesis of specific antibodies is an immunological method of choice for retrospective analysis. However, such analysis requires serum and paired $\mathrm{CSF}$, which are rarely available.

Commercial serological tests have been used to investigate viral agents in the routine of CSF analysis. This practice may lead to a decrease in the accuracy of the test due to the lower concentration of CSF immunoglobulin compared to serum if there is no previous adaptation and validation of the method. This procedure should consider the modifications of already validated bioanalytical methods, as well as matrix change ${ }^{8}$. The aim of this study was to adapt a commercial kit anti-HSV IgG used for serum samples to be performed with CSF samples, increasing the accuracy of the laboratory diagnosis of HSV infection in the CNS. In addition, the study evaluates the combined use of immunological and molecular tests to support the diagnosis of HSV infection in the CNS.

\section{METHODS}

A panel of 40 CSF samples from 38 patients with a suspected diagnosis of HSV infection in the CNS was evaluated in this study. Two of them had samples analyzed at two different times. All had negative CSF tests for bacterial, fungal or syphilis infections. Routine CSF examination included total and differential cell count, protein and glucose concentration, stain and culture to bacteria and fungi.

First, a pool of six reactive CSF samples for anti-HSV-1/2 IgG SYM (Symbiosys Diagnóstica, Brazil) was serially diluted (1:2 to 1:160) in two stages to obtain a better dilution, using a commercial kit HSV-1/2 IgG EIA (DiaSorin, Italy). In the next step, repeatability assay with twenty replicates on the same day and reproducibility assay with triplicates over the course of 20 days were performed with the pool of CSF.

We performed nested real-time PCR by Sybr Green system for the detection of HSV DNA in all 40 clinical samples, according to the protocol described by Kawada et al. ${ }^{9}$.

\section{Statistical analysis}

The repeatability and reproducibility assays were evaluated by the mean, standard deviation (SD), and coefficient of variation (CV) using the GraphPad Prism statistical program. The association between EIA and PCR for HSV and CSF findings (cell count and protein) was performed with the nonparametric Mann Whitney test of the SPSS program. The existence of association was considered for $p$-value $<0.05$. In the comparison between the results of the EIA test and PCR, the agreement was analyzed with Kappa $(\mathrm{K})$ value, being $\mathrm{K} \leq 0.20$ without agreement and K>0.80 optimal agreement. This analysis was performed by SAS System software (SAS Institute, Inc., North California, USA). The present study was approved according to the Ethical Review Board of HUCFF/UFRJ.

\section{RESULTS}

Out of the panel of 40 CSF samples from 38 patients with suspected diagnosis of HSV infection in the CNS, 55.3\% $(21 / 38)$ were women, with a median (min-max) age of 36 (1-90). The suspected diagnosis of HSV infection in the CNS consisted of 20 cases of meningitis, 11 cases of encephalitis, six cases of myelitis, and one case of meningoencephalitis $^{7,10,11}$. Signs and symptoms included ulcerative lesions in the mouth, genital lesions, headache, fever, vomiting, diplopia, convulsive attacks, disturbance of consciousness, quadriplegia, paraplegia, myalgia, memory deficit, and frontotemporal hemorrhagic lesion, as evidenced by brain magnetic resonance imaging. Among the CSF samples, 65\% (26/40) had pleocytosis $\left(>4\right.$ cells $\left./ \mathrm{mm}^{3}\right)$ and $50 \%$ (20/40) had hyperproteinorrhachia (>40 mg/dL). The median (min-max) leukocyte count was 15.5 (1-390) cells $/ \mathrm{mm}^{3}$, and the median (minmax) protein was 39.5 (15-890) $\mathrm{mg} / \mathrm{dL}$ (Table 1).

Considering that the best optical density (OD) values are between 0.5-1.5 for the EIA test, the 1:40 dilution was chosen as the mean OD value of 1.115 of the reactive CSF pool (Table 2). In the repeatability and reproducibility assays for the $1: 40$ dilution, we found 4.5 and $10.2 \%$ of $C V$, respectively.

Table 1. Inflammatory cerebrospinal fluid samples from 38 patients with a suspected diagnosis of herpes simplex virus infection in the central nervous system.

\begin{tabular}{lcccc} 
& Encephalitis $(n=13)$ & Meningitis $(n=18)$ & Meningoencephalitis $(n=2)$ & Myelitis $(n=7)$ \\
\hline Pleocytosis & 7 & 12 & 2 & 4 \\
$>4$ cells $/ \mathrm{mm}^{3}(\%)$ & $(53.9 \%)$ & $(66.7 \%)$ & $(100 \%)$ & $(57.1 \%)$ \\
Protein & 6 & 9 & 1 & 3 \\
$>40 \mathrm{mg} / \mathrm{dL}(\%)$ & $(46.2 \%)$ & $(50.0 \%)$ & $(50.0 \%)$ & $(48.9 \%)$ \\
\hline
\end{tabular}

Reference values: global count cell $\leq 4$ cells $/ \mathrm{mm}^{3}$; Protein: $15-40 \mathrm{mg} / \mathrm{dL}$. 
Both values are acceptable according to ANVISA's ${ }^{8}$ determination that considers a CV up to $15 \%$. Repeatability and reproducibility assays were also performed for a minimum empirical dilution of 1:2 in an attempt to increase the sensitivity of the test by detecting lower concentrations of antiHSV IgG in the CSF. The repeatability and reproducibility assays for this dilution were 1.8 and $13.6 \%$, respectively.

Table 2. Serial dilution of the pool of six previously reactive cerebrospinal fluid samples for anti-HSV-1/2 lgG using a commercial kit HSV-1/2 lgG EIA .

\begin{tabular}{ccccc}
\multicolumn{2}{c}{$1^{\text {st }}$ step of dilution } & & \multicolumn{2}{c}{$2^{\text {nd }}$ step of dilution } \\
\cline { 1 - 2 } Dilution & $\begin{array}{c}\text { Mean of OD } \\
\text { duplicates values }\end{array}$ & & Dilution & $\begin{array}{c}\text { Mean of OD } \\
\text { duplicates values }\end{array}$ \\
\cline { 1 - 2 } Cut-off & 0.235 & & $1: 10$ & 1.809 \\
$1: 2$ & 1.837 & & $1: 20$ & 1.629 \\
$1: 4$ & 1.874 & & $1: 40$ & 1.115 \\
$1: 8$ & 1.755 & & $1: 80$ & 0.640 \\
$1: 16$ & 1.302 & & $1: 100$ & 0.581 \\
\hline $1: 32$ & 0.425 & $1: 160$ & 0.378 \\
\hline
\end{tabular}

OD: optic density.
Of the 40 CSF samples analyzed, $5 \%$ of the samples were reactive for HSV IgG EIA at 1:40 dilution, $65 \%$ were reactive at 1:2 dilution, and $15 \%$ of the samples amplified the viral DNA by PCR. Three of the samples that amplified in PCR were also reactive in EIA at 1:2 dilution. None of the samples that amplified in PCR were reactive in EIA at 1:40 dilution (Table 3).

The combined analysis of immunological tests and molecular biology were positive in 20\% (EIA at dilution 1:40 and PCR) and $72.5 \%$ (EIA at dilution 1:2 and PCR) of the CSF samples. Increased cell count and protein values in CSF were associated with positive PCR in 40 samples (Tables 4 and 5). A trend of association of reactive EIA at dilution 1:40 $(\mathrm{p}=0.18)$ was observed with high levels of protein in the CSF. However, this tendency cannot be considered, because only a few samples were reactive (2/40). Kappa (K) index showed no agreement between reactive anti-HSV IgG by EIA and positive PCR for HSV (Table 3).

\section{DISCUSSION}

In the present study, in order to increase the diagnosis accuracy in cases of CNS infection by HSV with negative PCR,

Table 3. Profile of 40 samples from 38 patients with a suspected diagnosis of herpes simplex virus infection in central nervous system.

\begin{tabular}{|c|c|c|c|c|c|c|c|}
\hline Samples & Clinical diagnosis & $\begin{array}{l}\text { Age/ } \\
\text { gender }\end{array}$ & Cell count $/ \mathrm{mm}^{3}$ & Protein mg/dL & PCR & $\begin{array}{l}\text { IgG anti- HSV EIA } \\
\text { (dilution 1:40) }\end{array}$ & $\begin{array}{l}\text { IgG anti- HSV EIA } \\
\text { (dilution 1:2) }\end{array}$ \\
\hline 1 & Myelitis & $55 / F$ & 21 & 28 & $\mathrm{Neg}$ & NR & $\mathrm{R}$ \\
\hline *2 & Follow up & $55 / F$ & 9 & 39 & $\mathrm{Neg}$ & NR & $\mathrm{R}$ \\
\hline 3 & Myelitis & $31 / F$ & 3 & 16 & $\mathrm{Neg}$ & NR & $\mathrm{R}$ \\
\hline 4 & Meningoencephalitis & $58 / \mathrm{M}$ & 5 & 57 & $\mathrm{Neg}$ & NR & $R$ \\
\hline 5 & Myelitis & $23 / F$ & 2 & 35 & $\mathrm{Neg}$ & NR & $\mathrm{R}$ \\
\hline 6 & Myelitis & $32 / F$ & 0 & 54 & $\mathrm{Neg}$ & NR & $\mathrm{R}$ \\
\hline 7 & Myelitis & $18 / \mathrm{M}$ & 309 & 890 & Pos & NR & NR \\
\hline 8 & Encephalitis & $54 / F$ & 26 & 44 & $\mathrm{Neg}$ & NR & NR \\
\hline$\star \star 9$ & Follow up & & 3 & 38 & $\mathrm{Neg}$ & NR & NR \\
\hline 10 & Encephalitis & $16 / F$ & 2 & 15 & $\mathrm{Neg}$ & NR & NR \\
\hline 11 & Encephalitis & $3 / F$ & 106 & 16 & $\mathrm{Neg}$ & NR & NR \\
\hline 12 & Encephalitis & $54 / F$ & 8 & 23 & $\mathrm{Neg}$ & NR & $\mathrm{R}$ \\
\hline 13 & Encephalitis & $46 / F$ & 3 & 24 & Neg & NR & NR \\
\hline 14 & Encephalitis & $60 / M$ & 6 & 40 & $\mathrm{Neg}$ & NR & $\mathrm{R}$ \\
\hline 15 & Encephalitis & $90 / \mathrm{M}$ & 1 & 45 & Pos & NR & $\mathrm{R}$ \\
\hline 16 & Encephalitis+HIV & $35 / F$ & 1 & 49 & $\mathrm{Neg}$ & NR & $\mathrm{R}$ \\
\hline 17 & Encephalitis & $40 / F$ & 170 & 49 & $\mathrm{Neg}$ & NR & $\mathrm{R}$ \\
\hline 18 & Encephalitis & $35 / M$ & 40 & 69 & $\mathrm{Neg}$ & NR & $\mathrm{R}$ \\
\hline 19 & Encephalitis & $61 / \mathrm{M}$ & 96 & 81 & $\mathrm{Neg}$ & NR & $\mathrm{R}$ \\
\hline 20 & Encephalitis & 44/F & 2 & 30 & $\mathrm{Neg}$ & NR & $\mathrm{R}$ \\
\hline 21 & Meningitis & $1 / F$ & 2 & 15 & $\mathrm{Neg}$ & NR & $\mathrm{R}$ \\
\hline
\end{tabular}


Table 3. Continuation.

\begin{tabular}{|c|c|c|c|c|c|c|c|}
\hline Samples & Clinical diagnosis & $\begin{array}{l}\text { Age/ } \\
\text { gender }\end{array}$ & Cell count $/ \mathrm{mm}^{3}$ & Protein mg/dL & PCR & $\begin{array}{l}\text { IgG anti- HSV EIA } \\
\text { (dilution 1:40) }\end{array}$ & $\begin{array}{l}\text { IgG anti- HSV EIA } \\
\text { (dilution 1:2) }\end{array}$ \\
\hline 22 & Meningitis & $3 / F$ & 75 & 24 & Neg & NR & $\mathrm{R}$ \\
\hline 23 & Meningitis & $72 / \mathrm{M}$ & 1 & 25 & $\mathrm{Neg}$ & NR & NR \\
\hline 24 & Meningitis & $3 / \mathrm{M}$ & 229 & 29 & Neg & NR & NR \\
\hline 25 & Meningitis & $36 / F$ & 4 & 31 & Neg & NR & $\mathrm{R}$ \\
\hline 26 & Meningitis & $33 / F$ & 187 & 37 & Pos & NR & NR \\
\hline 27 & Meningitis & $38 / \mathrm{M}$ & 283 & 45 & $\mathrm{Neg}$ & NR & NR \\
\hline 28 & Meningitis & $36 / \mathrm{M}$ & 2 & 48 & $\mathrm{Neg}$ & $\mathrm{R}$ & $\mathrm{R}$ \\
\hline 29 & Meningitis & 48/M & 11 & 54 & $\mathrm{Neg}$ & NR & $\mathrm{R}$ \\
\hline 30 & Meningitis & $15 / F$ & 128 & 60 & $\mathrm{Neg}$ & NR & $\mathrm{R}$ \\
\hline 31 & Meningitis & $55 / M$ & 1 & 89 & Neg & NR & $\mathrm{R}$ \\
\hline 32 & Meningitis & $51 / F$ & 331 & 91 & Pos & NR & $\mathrm{R}$ \\
\hline 33 & Meningitis & $42 / \mathrm{M}$ & 213 & 99 & Pos & NR & $\mathrm{R}$ \\
\hline 34 & Meningitis & $25 / F$ & 390 & 118 & Pos & NR & NR \\
\hline 35 & Meningitis+HIV & $39 / F$ & 28 & 382 & Neg & $\mathrm{R}$ & $\mathrm{R}$ \\
\hline 36 & Meningitis & $55 / \mathrm{M}$ & 20 & 21 & Neg & NR & $\mathrm{R}$ \\
\hline 37 & Meningitis+HIV & $6 / \mathrm{M}$ & 208 & 36 & Neg & NR & $\mathrm{R}$ \\
\hline 38 & Meningitis Sepse & $1 / F$ & 8 & 18 & Neg & NR & NR \\
\hline 39 & Meningoencephalitis & $1 / \mathrm{M}$ & 123 & 27 & Neg & NR & $N R$ \\
\hline 40 & Myelitis & $26 / M$ & 42 & 56 & Neg & NR & NR \\
\hline
\end{tabular}

n: number of the serum and CSF samples, F: female, M: male; NR: non-reactive, R: reactive; *CSF control sample of sample 1 (same patient); EIA: Enzyme-Linked Immunosorbent Assay; PCR: polymerase chain reaction; ${ }^{*} \mathrm{CSF}$ control sample of sample 8 (same patient). Reference values: cell count $\leq 4$ cells $/ \mathrm{mm}^{3}$; protein $\leq 40 \mathrm{mg} / \mathrm{dL}$.

Table 4. Association between different dilutions of Enzyme-Linked Immunosorbent Assay and polymerase chain reaction for herpes simplex virus with cell count in 40 cerebrospinal fluid samples from 38 patients with a suspected diagnosis of herpes simplex virus infection in the central nervous system.

\begin{tabular}{lcc}
\hline $\begin{array}{l}\text { Tests (dilution) } \\
\text { EIA (1:40) (cytologyitologia) }\end{array}$ & Cell count Median (min-max) & p-value \\
\hline Reactive & $15(2-28)$ & \\
Non-reactive & $15.5(0-390)$ & 0.615 \\
EIA (1:2) & & \\
Reactive & $8.5(0-331)$ & 0.113 \\
Non-reactive & $74(1-390)$ & \\
PCR & & \\
Positive & $261(1-390)$ & 0.010 \\
Negative & $8.5(0-283)$ & \\
\hline
\end{tabular}

we adapted a serological assay for the detection of anti-HSV IgG for CSF analysis, since the commercial kits usually used are for the evaluation of serum samples ${ }^{12}$. Specific EIA tests for serum are used in the laboratory routine for CSF analyses, not rarely without previous adaptation. Otherwise, some criteria
Table 5. Association between different dilutions of Enzyme-Linked Immunosorbent Assay and polymerase chain reaction for herpes simplex virus with protein dosage in 40 cerebrospinal fluid samples from 38 patients with a suspected diagnosis of herpes simplexvirus infection in the central nervous system.

\begin{tabular}{lcc}
\hline Tests (dilution) & Protein median (min-max) & p-value \\
\hline EIA (1:40) & $215(48-382)$ & \\
Reactive & $38.5(15-890)$ & 0.185 \\
Non-reactive & & \\
EIA (1:2) & $46.5(15-382)$ & 0.197 \\
Reactive & $33(15-890)$ & \\
Non-reactive & & \\
PCR & $95(37-890)$ & 0.006 \\
Positive & $37(15-382)$ & \\
Negative & & \\
\hline EIA: Enzyme-Linked Immunosorbent Assay; PCR: polymerase chain reaction.
\end{tabular}

are important for the validation of a diagnostic method: its results must corroborate the suspected diagnosis, be evaluated repeatedly and reproducible in the same and in different laboratories ${ }^{8,12}$. Nonetheless, the validation of methods for CSF analysis may present some limitations in its applicability, 
such as noble sample obtained with invasive methods, scarce material and few standardized tests for use as reference or gold standard. For the development of a new laboratory test, there are some accepted methodologies. One of them consists of comparing the results of a laboratory test to a clinical diagnosis, based on the symptoms and/or physical exams of the patients that make up the analysis ${ }^{8,12}$. These are situations in which an imperfect pattern is accepted, which, although not considered ideal by the consensus of experts, may still provide results that are closer to the diagnostic reality ${ }^{8,12}$.

The clinical diagnosis suspicion of HSV infection in the CNS together with CSF findings (cell counts, protein and glucose dosage, exclusion of other infections) was the reference in this analysis. The immunological tests and PCR were used to support the laboratorial diagnosis. This type of approach poses limitations in the case of retrospective evaluations, but it is more comprehensive because it allows analyzing distinct phases of the disease (multiple parallel tests). Not all patients were in the acute phase, or untreated, to consider PCR as the gold standard, although this was done in all of them. In fact, the reactive anti-HSV IgG by EIA is not a definition criteria for acute infection in the CNS, but may be helpful to support the retrospective diagnosis.

Most of the patients (77.5\%) presented a CSF examination compatible with viral infection (pleocytosis with lymphocyte predominance and/or hiperproteinorrachia and normal glucose). Pleocytosis ( $>4$ cells $/ \mathrm{mm}^{3}$ ) and hiperproteinorrachia ( $>40 \mathrm{mg} / \mathrm{dL}$ ) were found in 65 and $50 \%$ of the cases, respectively. Ward et al. ${ }^{13}$ found pleocytosis in $75 \%(12 / 16)$ of the CSF samples analyzed for patients with HSV infection in the CNS, whereas hiperproteinorrachia was detected in $71.4 \%(10 / 14)$ of them. In accordance with our results, Whitley reported that $50 \%$ of the individuals with herpetic encephalitis showed a normal concentration of protein in the first week of the infection ${ }^{14}$. Riera-Mestre et al. described an increase in leucocytes count in $77 \%$ of the CSF samples of 35 patients with encephalitis by HSV, and the protein concentration remained $>40 \mathrm{mg} / \mathrm{dL}$ in $94.3 \%$ of the cases ${ }^{15}$.

In relation to the comparison between the EIA tests in the present study, the dilution 1:40 of CSF samples showed excellent results in the repeatability and reproducibility assays. There was no agreement between 1:2 and 1:40 dilutions of EIA. The lower dilution (1:2) presented good laboratory performance (repeatability and reproducibility), besides a higher sensitivity $(65 \%)$ for the detection of lower concentrations of antibodies found in the 40 CSF samples of the 38 patients with suspected HSV infection in their CNS. There was no agreement between PCR with EIA at various dilutions, since immunological tests became reactive around the tenth day after the onset of the first symptoms, whereas the PCR was positive at the onset of the disease, before treatment ${ }^{16}$.

The results of the molecular biology test on HSV infection in the CNS can be influenced by the duration of symptoms and the use of anti-viral drugs ${ }^{17}$. Although PCR represents gold-standard for diagnosis (95\% sensitivity and 100\% specificity), its sensitivity decreases after the acute phase of the disease, due to reduced virus replication activity ${ }^{18}$. At this time, the immune system begins to produce specific antibodies against the viral agent, which may persist for years ${ }^{6,7}$. The concentration of HSV antibodies in CSF can increase up to four times, reaching sensitivity at $85 \%$ detection after one month of disease onset ${ }^{14}$.

This study demonstrates the importance of a previously adaptation of commercial serological tests for use in CSF samples to obtain higher accuracy. The adaptation of dilution for CSF was a good alternative for retrospective screening of specific anti-HSV IgG antibodies in the CSF. It may contribute to the CNS HSV diagnosis in suspected cases when PCR is already negative. The combined analysis of immunological tests and PCR showed a greater comprehensiveness in the HSV infection in the CNS, considering the different stages of the disease. Viral DNA detection was predominant in inflammatory CSF samples consistent with the acute and active phase of the disease. Such findings confirm that the signs of acute inflammatory CSF represents a marker for HSV activity.

\section{ACKNOWLEDGMENTS}

The authors thank Dr. Carlos Otavio Brandão and Dr. Ricardo Canuto, from Neurolife Laboratory, Rio de Janeiro, RJ, Brazil, for yielding the reactive anti-HSV IgG CSF samples for this study, and Dr. Ismar Barbosa, from Quality Program of the Brazilian Society of Clinical Pathology for reviewing this manuscript. Mrs. Samya Jezyne received a master science scholarship from Coordenação de Aperfeiçoamento de Pessoal de Nivel Superior - CAPES - at the Graduation Program in Infectious and Parasitic Diseases at Universidade Federal do Rio de Janeiro (UFRJ).

\section{References}

1. Ryu W. Herpesviruses. In: Ryu W, Molecular Virology of Human Pathogenic Viruses. London: ELSEVIER; 2017. p.125-39.

2. Patoulias D, Koutras C. HSV encephalitis: is the insight of the clinician still crucial for the outcome? Folia Med Cracov. 2017;57(4):97-105.

3. Soares BP, Provenzale JM. Imaging of Herpes virus Infections of the CNS. AJR Am J Roentgenol. 2016 Jan;206(1):39-48. https://doi. org/10.2214/AJR.15.15314
4. Hogestyn JM, Mock DJ, Mayer-Proschel M. Contributions of neurotropic human herpesviruses herpes simplex virus 1 and human herpesvirus 6 to neurodegenerative disease pathology. Neural Regen Res. 2018 Feb;13(2):211-21. https://doi.org/10.4103/1673-5374.226380

5. Adler AC, Kadimi S, Apaloo C, Marcu C. Herpes simplex encephalitis with two false-negative cerebrospinal fluid PCR tests and review of negative PCR results in the clinical setting. Case Rep Neurol. 2011 May/Aug;3(2):172-8. https://doi.org/10.1159/000330298 
6. Akçali A, Ozkaya E, Yilmaz D, Uyar Y, Oncül O. Investigation of herpes simplex virus in viral meningoencephalitis suspected cases using molecular and serological methods. Mikrobiyol Bul. 2008 Jul;42(3):421-8.

7. Studahl M, Lindquist L, Eriksson BM, Günther G, Bengner $M$, Franzen-Röhl E, et al. Acute viral infections of the central nervous system in immunocompetent adults: diagnosis and management. Drugs. 2013 Feb;73(2):131-58. https://doi. org/10.1007/s40265-013-0007-5

8. Agência Nacional de Vigilância Sanitária (ANVISA). Brasil. Ministério da Saúde ICdBL. Resolução nº 899, 29 de maio de 2003, determina a publicação do "Guia para a validação de métodos analíticos e bioanalíticos". Available from: http://portal.anvisa.gov.br/ documents/10181/2718376/RE_899_2003_COMP.pdf/ff6fdc6b3ad1-4d0f-9af2-3625422e6f4b

9. Kawada J, Kimura H, Ito Y, Hoshino Y, Tanaka-Kitajima N, Ando Y, Futamura M, Morishima T. Comparison of real-time and nested PCR assays for detection of herpes simplex virus DNA. Microbiol Immunol. 2004;48(5):411-5. https://doi.org/10.1111/j.1348-0421.2004. tb03530.x

10. Nielsen KE, Knudsen TB. Elsberg syndrome. Ugeskr Laeger. 2013 Dec;175(51):pii:V01130085.

11. Steiner I, Benninger F. Update on herpes virus infections of the nervous system. Curr Neurol Neurosci Rep. 2013 Dec;13(12):414. https://doi.org/10.1007/s11910-013-0414-8
12. Agência Nacional de Vigilância Sanitária (ANVISA). Brasil. Ministério da Saúde. Resolução da Diretoria Colegiada - RDC No. 302, de 13 de outubro de 2005. Brasília: Ministério da Saúde.

13. Ward KN, Ohrling A, Bryant NJ, Bowley JS, Ross EM, Verity Cm. Herpes simplex serious neurological disease in young children: incidence and long-term outcome. Arch Dis Child. 2012;97(2):162-5. http://dx.doi.org/10.1136/adc.2010.204677

14. Whitley RJ. Herpes simplex encephalitis: adolescents and adults. Antiviral Res. 2006 Sep;71(2-3):141-8. https://doi.org/10.1016/j. antiviral.2006.04.002

15. Riera-Mestre A, Gubieras L, Martínez-Yelamos S, Cabellos C, Fernández-Viladrich P. Adult herpes simplex encephalitis: fifteen years' experience. Enferm Infecc Microbiol Clin. 2009 Mar;27(3):1437. https://doi.org/10.1016/j.eimc.2008.05.006

16. Denes E, Labach C, Durox H, Adoukonou T, Weinbreck P, Magy L, et al. Intrathecal synthesis of specific antibodies as a marker of herpes simplex encephalitis in patients with negative PCR. Swiss Med Wkly. 2010 Oct;140:w13107. https://doi.org/10.4414/smw.2010.13107

17. Kamei S, Takasu T, Morishima T, Mizutani T. Serial changes of intrathecal viral loads evaluated by chemiluminescence assay and nested PCR with aciclovir treatment in herpes simplex virus encephalitis. Intern Med. 2004 Sep;43(9):796-801. https://doi. org/10.2169/internalmedicine.43.796

18. Tyler KL. Update on herpes simplex encephalitis. Rev Neurol Dis. 2004 Fall;1(4):169-78. 